Helgoländer wiss. Meeresunters. 25, 126-134 (1973)

\title{
Synthetic sea water as a medium for raising crab larvae
}

\author{
S. D. Sulkin \& L. L. Minasian \\ Natural Resources Institute, University of Maryland; \\ Solomons, Maryland, USA
}

KURZFASSUNG: Synthetisches Meerwasser als ein Medium für die Aufzucht von Krebslarven. Der brachyure Krebs Rhitbropanopeus harrisii (GouLD) wurde bis zum MegalopaStadium in natürlichem Meerwasser und in zwei synthetischen Medien („Instant Ocean" und "Utility Seven Seas Marine Mix") bei Salinitäten von $3 \%$ und $11 \%$ aufgezogen. Die Überlebensrate der Zoea-Larven wurde weder durch die Art des Mediums noch durch den Salzgehalt beeinflußt, die der Megalopa-Larven war jedoch bei $3 \% 0$ in allen drei Medien signifikant geringer als bei $11 \%$. Die Megalopa-Stadien zeigten bei $11 \%$ in allen Versuchsreihen keine wesentlichen Unterschiede in bezug auf Entwidklungsgeschwindigkeit und Sterblichkeit. Die beiden getesteten, in den USA kommerziell vertriebenen synthetischen Kulturmedien erwiesen sich somit zur Aufzucht von $R$, harrisii als brauchbar. Es wird empfohlen, die Eignung derartiger Medien - sofern sie für Massenkulturen bestimmter Arten eingesetzt werden sollen - anhand möglichst verschiedener Kriterien (Einfluß auf die Entwicklung, spezifische ionale Zusammensetzung, Kaufpreis etc.) $z \mathfrak{u}$ bewerten.

\section{INTRODUCTION}

The availability of commercially prepared synthetic sea salts as culture media for marine invertebrate larvae promises to expand the potential research effort to laboratories and investigators with no ready access to natural sea water. Species that have been successfully raised in synthetic sea salts include the oyster Ostrea edulis (Mrllar \& ScotT 1968), the sea urchin Lytechinus variegatus (MAzur \& Miller 1971), and the calanoid copepod Acartia tonsa (HennLe 1969). Reproductive success was poor in another calanoid copepod Eurytemora affinis, reared in synthetic sea water (HEINLE 1969).

Synthetic sea water could provide a useful tool for examining the influence of specific media constituents on development, since components may be controlled. There is evidence to suggest that water quality does influence larval development. WiLson $(1951,1958)$ reported that polychaete and echinoderm larvae fared better in Celtic Sea water than in water collected in the English Channel. Ewald (1965) found that in simultaneous laboratory experiments, late larval stages of the decapod Penaeus duorarum exhibited a higher survival in open ocean Gulf Stream water than in Biscayne Bay water of the same temperature, salinity, and $\mathrm{pH}$. It is not clear whether such differential rearing success is due to the presence of beneficial components in one 
medium, or to harmful components in the other. Such components, where they exist, may be either organic or inorganic in nature.

In this study, larvae of the xanthid crab Rhithropanopeus barrisii were raised in natural sea water and in two commercially available synthetic sea salts, to determine whether synthetic sea water is a suitable culture medium for experimental studies on crab development.

\section{MATERIALS AND METHODS}

Rbitbropanopeus harrisii (GouLD) was chosen for experimentation because gravid specimens were readily available, and the complete larval development has been described (ConNolly 1925, Chamberlain 1962). Rates of development and survival in various temperature-salinity combinations have been reported (CHAmberLaIN 1962, Costlow et al. 1966). The development is characterized by four zoea stages and one megalopa.

Culture media used during the course of the experiments included natural sea water, "Instant Ocean", (Aquarium Systems, Inc., 33208 Lakeland Blvd., Eastlake, Ohio 44094, USA), and "Utility Seven Seas Marine Mix", (Utility Chemical Company, 145 Peel Street, Paterson, N.J., USA). Larvae were raised in each of the above-mentioned media diluted to $3 \%$ and $11 \%$. These two salinities were chosen because the former is near the lower limit for good survival, and the latter is within optimal rearing conditions (CostLow et al. 1966).

Fresh sea water was collected in the surf near Indian Inlet, Delaware, USA. It was transported to the laboratory at Solomons, Maryland, USA, in 5-gal linear polyethylene jerricans. The water was passed through a $5 \mu$ mesh filter bag into a 55 -gal linear polyethylene storage tank. The salinity was $32 \%$. Each of the two synthetic blends was prepared in 55-gal linear polyethylene storage tanks. Salinity was measured at $34 \%$ for each mixture. All three stock solutions were aerated periodically.

Each stock solution was diluted to $3 \%$ and $11 \% 0 \mathrm{~S}$, and kept in 5-gal polyethylene jerricans. Sufficient quantities of each dilution were prepared for the entire experiment. The six test solutions were stored in a culture cabinet set at $25^{\circ} \mathrm{C}$.

Ovigerous females of Rhithropanopeus harrisii were collected from oyster trays in the Patuxent River, Maryland. Ambient salinity and temperature at time of collection was $9.7 \%$ and $25.9^{\circ} \mathrm{C}$. Ovigerous crabs were placed in large glass bowls filled with filtered Patuxent River water and kept at room temperature $\left(25^{\circ} \mathrm{C}\right)$ and under natural light conditions for two days. Egg masses were then inspected for stage of development. In order that acclimation time be approximately equal for all groups, further experimentation was conducted only on those egg masses in which the zoea eyes were well developed. Egg masses chosen for further study were teased apart with dissecting needles. Each egg mass was divided evenly among six $125 \mathrm{ml}$ Erlenmeyer flasks, each containing $50 \mathrm{ml}$ of one of the test solutions. The flasks were then placed upon a reciprocating variable speed shaker set at $110 \mathrm{rpm}$ (CosTLOW \& BooKHout

*Hereater, the following abbreviations will be used to designate the three media: nsw = natural sea water; $1 O=$ "Instant Ocean"; 7-S = "Utility Seven Seas Marine Mix". 
1960). Eggs were examined daily, but the water was not changed. Successful hatching occurred in all six tests solutions.

When hatching occurred, larvae in each test solution were separated into a number of small glass bowls, 10 zoeae per bowl. The bowls were examined daily for the number and stage of living and dead larvae. Living zoeae were transferred to clean bowls containing the appropriate test solution, and Artemia salina nauplii were added as food. When the megalopa stage was reached, each individual was kept in a separate compartment of a sub-divided plastic box. All stages were kept in culture cabinets set at $25^{\circ} \mathrm{C}$ and $12 \mathrm{hrs}$ of light for the duration of each experiment.

Survival and rates of development are the criteria used in comparing the various solutions. Methods of data analysis are described with the results. Values obtained are based on six independent tests with larvae from three different crabs.

\section{RESULTS}

\section{Hatching}

Although no quantitative data were collected, it was apparent that hatching occurred successfully in all six test solutions. Larvae produced were vigorous and viable.

\section{Survival}

A high percentage of the deaths occurred at the time of molt. Dead larvae were characterized by a greatly swollen carapace or, in some cases, by being halfway out of the old carapace. These larvae were recorded as reaching the stage after the molt.

Figure 1 shows survivorship plotted as a function of stage of development for larvae raised in all six test solutions. Each point is an average of values obtained in six different rearing experiments. The relationship between survival and stage of development is evident. Survival is high through the four zoea stages in all test solutions but drops sharply during the megalopa stage.

In order to compare the per cent mortality that occurred during each larval stage among the various experiments, calculations were made using the following equation (derived from RoBERTs 1971):

$$
M_{i}=\frac{\sum_{1}^{y}\left[\frac{N_{i-1}-N_{i}}{N_{i-1}}\right]}{y} \times 100
$$

where $\mathrm{M}_{\mathrm{i}}=$ per cent mortality during stage $\mathrm{i}, \mathrm{i}=$ a particular stage of development, $\mathrm{N}_{\mathrm{i}}=$ number of larvae surviving stage $\mathrm{i}, \mathrm{N}_{0}=$ number of larvae at beginning of experiment $(\mathrm{i}=0), \mathrm{Y}=$ number of experimental repetitions.

The per cent mortalities that occurred during each stage of development are shown in Table 1. The zoea stages show low and similar mortalities among the six test solutions, as indicated by the survivorship curves (Fig. 1). Mortality ranged from 0 to $15 \%$, with the highest values obtained during the first zoea stage. A two-way 


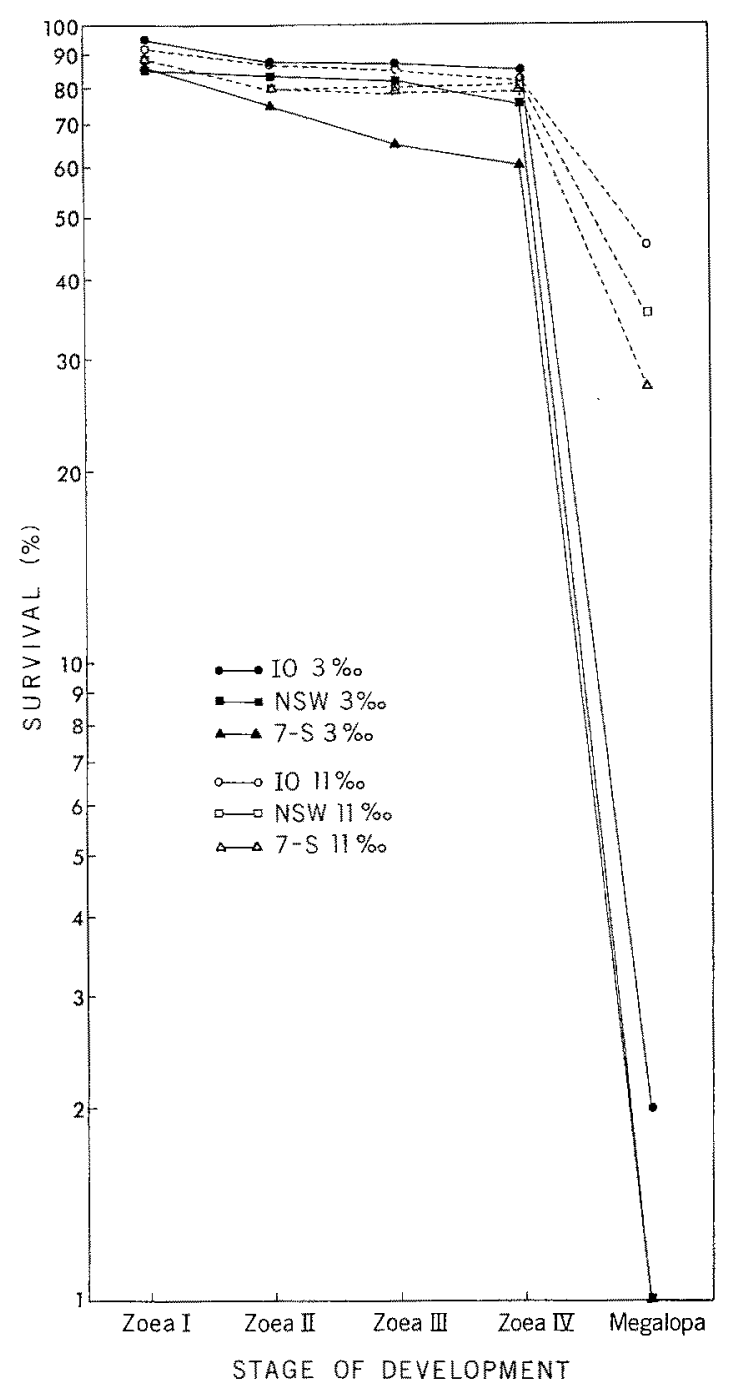

Fig. 1: Survivorship curves for larvae raised in six different test solutions. Survivorship plotted as a function of stage of development

analysis of variance on cumulative zoea mortality indicates no significant differences due either to salinity or to medium, and no interaction between these factors (Table 2). A two-way analysis of variance indicates highly significant differences between megalopa mortality at $3 \%$ and at $11 \% 0 \mathrm{~S}$. Although differences in mortality among the three media are apparent, this analysis of variance shows only a marginally significant difference. No interaction between medium and salinity is evident (Table 2). The difference in survivorship between $3 \%$ and $11 \% 0 \mathrm{~S}$ is due almost entirely to the extremely high megalopa mortality at the lower salinity. 
Table 1

Per cent mortality for each larval stage, for cumulative zoea development, and for cumulative development to the first crab stage

\begin{tabular}{|ccrrrrrrr}
\hline Salinity & Medium & $\begin{array}{c}\text { Zoea } \\
\text { I }\end{array}$ & $\begin{array}{c}\text { Zoea } \\
\text { II }\end{array}$ & $\begin{array}{c}\text { Zoea } \\
\text { III }\end{array}$ & $\begin{array}{c}\text { Zoea } \\
\text { IV }\end{array}$ & $\begin{array}{c}\text { Cumulative } \\
\text { zoea } \\
\text { mortality }\end{array}$ & $\begin{array}{c}\text { Mega- } \\
\text { lopa }\end{array}$ & $\begin{array}{c}\text { Cumulative } \\
\text { larval } \\
\text { mortality }\end{array}$ \\
\hline \multirow{3}{*}{$3 \% 0$} & nsw & 15 & 2 & 1 & 9 & 25 & 100 & 100 \\
& IO & 5 & 7 & 1 & 2 & 15 & 98 & 98 \\
& $7-S$ & 13 & 14 & 13 & 8 & 40 & 100 & 100 \\
& nsw & 13 & 8 & 0 & 0 & 20 & 56 & 65 \\
& IO & 8 & 5 & 2 & 2 & 17 & 46 & 55 \\
& 7-S & 13 & 8 & 0 & 0 & 20 & 66 & 73 \\
\hline
\end{tabular}

Table 2

Probabilities associated with the two-way analysis of variance on the effects of salinity and culture medium on mortality

\begin{tabular}{|ccc|}
\hline & $\begin{array}{c}\text { Cumulative zoea } \\
\text { development }\end{array}$ & $\begin{array}{c}\text { Per cent mortality* } \\
\text { development }\end{array}$ \\
\hline Salinity & $0.10<\mathrm{p}<0.25$ & $\mathrm{p}<0.001$ \\
Medium & $0.25<\mathrm{p}<0.50$ & $0.05<\mathrm{p}<0.10$ \\
Interaction & $0.50<\mathrm{p}<0.75$ & $0.25<\mathrm{p}<0.50$ \\
* Per cent mortality values subjected to angular transformation before statistical tests \\
\hline
\end{tabular}

\section{Rate of development}

Rate of development was calculated as mean intermolt time for each stage, and on a cumulative basis for zoea and megalopa development. Intermolt time for each stage of development was calculated on the basis of six independent determinations as follows:

$$
R_{j}=\frac{\sum_{1}^{y}\left(T_{j}-T_{j-1}\right)}{Y}
$$

where $R_{j}=$ intermolt duration for stage $j, Y=$ no. of experimental repetitions, $\mathrm{T}_{\mathrm{j}}=$ cumulative time of development through stage $\mathrm{j}$, calculated as follows:

$$
T_{j}=\frac{\sum_{i}^{d j}\left(n_{k} k\right)}{N_{j}}
$$

where $\mathrm{k}=$ a specific day of development (e.g., $\mathrm{k}=1$ : first day of development), $\mathrm{n}_{\mathrm{k}}=$ number of larvae molting on day $\mathrm{k}, \mathrm{N}_{\mathrm{j}}=$ total number of molts for stage $\mathrm{j}$, $\mathrm{d}_{\mathrm{j}}=$ number of days of development $(\mathrm{k})$ on which molts to stage $\mathrm{j}$ occurred.

Table 3 shows the intermolt time for each developmental stage, for cumulative zoea development, and for cumulative development to first crab. Rates of cumulative 
Table 3

Intermolt time (days) for each larval stage, for cumulative zoea development and for cumulative development to the first crab stage

\begin{tabular}{|ccccccccc|}
\hline Salinity & Medium & Zoea I & Zoea II & Zoea III & Zoea IV & $\begin{array}{c}\text { Cumul- } \\
\text { ative } \\
\text { zoea } \\
\text { devel- } \\
\text { opment }\end{array}$ & Megalopa & $\begin{array}{c}\text { Cumul- } \\
\text { ative } \\
\text { larval } \\
\text { devel- } \\
\text { opment }\end{array}$ \\
\hline \multirow{3}{3}{ 3\%o } & & & & & & & & \\
& nsw & 4.5 & 2.2 & 2.6 & 3.8 & 13.1 & - & - \\
& IO & 4.8 & 2.2 & 3.0 & 4.0 & 14.0 & 7.0 & 21.0 \\
& 7-S & 4.6 & 2.9 & 3.0 & 3.9 & 14.4 & - & - \\
& nsw & 4.4 & 2.2 & 2.5 & 3.8 & 12.9 & 5.8 & 18.7 \\
& IO & 4.5 & 2.2 & 2.4 & 3.9 & 13.0 & 5.5 & 18.5 \\
& $7-S$ & 4.6 & 2.5 & 2.5 & 3.9 & 13.5 & 6.5 & 20.0 \\
\hline
\end{tabular}

Table 4

Probabilities associated with the two-way analysis of variance on the effects of salinity and culture medium on rate of development

\begin{tabular}{|ccc|}
\hline & $\begin{array}{c}\text { Cumulative zoea } \\
\text { development }\end{array}$ & $\begin{array}{c}\text { Rate of development } \\
\text { Megalopa* } \\
\text { development }\end{array}$ \\
\hline Salinity & $0.005<\mathrm{p}<0.005$ & $0.05<\mathrm{p}<0.10$ \\
Medium & $0.10<\mathrm{p}<0.25$ & \\
Interaction & & \\
* One way analysis of variance &
\end{tabular}

zoea development for all six test solutions were subjected to a two-way analysis of variance. Significant differences were found, due both to salinity and to medium. No interaction was evident between these factors (Table 4). The data was subjected to the STUdent-NeumanN-Keul test to determine where the statistical differences fell. The results showed that both $\mathrm{IO}$ and 7-S had a longer zoea development than did nsw at $3 \%$. The two synthetic media at $3 \%$ were also significantly different from either nsw or $\mathrm{IO}$ at $11 \%$. The position of $7-\mathrm{S}$ at $11 \% \mathrm{~S}$ is equivocal (IO, $3 \%=7-\mathrm{S}, 3 \%$. $7-\mathrm{S}, 11 \% \mathrm{nsw}, 3 \%$. 3 nsw, $11 \%$ \% $=\mathrm{IO}, 11 \%$ ).

The results for the megalopa at $3 \%$ are difficult to analyze. The value shown in Table 3 is based on only one individual that survived to the first crab stage. Although the groups raised in 7-S medium at $11 \% \mathrm{~S}$ appeared to take slightly longer to molt than did those raised in the other two media, a one-way analysis of variance shows only marginal statistical difference (Table 4).

\section{DISCUSSION}

Using fitted response curves, Costiow et al. (1966) have estimated per cent mortality and rate of development for all larval stages of Rhitbropanopeus harrisii in 
natural sea water of various salinity-temperature combinations. Our results showed slightly lower zoea mortality and higher megalopa mortality at $3 \%$ than they reported. Mortality rates at $11 \% \mathrm{~S}$ were comparable to published results, as were rates of development at both salinities.

The fact that larvae required a longer time to reach the megalopa stage in synthetic sea water at $3 \%$ S than they did in either synthetic sea water at $11 \% 00 \mathrm{~S}$, or in natural sea water at $3 \% \mathrm{~S}$ may indicate that there is a threshold level of some constituent, or constituents. The concentration of such constituent(s) apparently was sufficient at $11 \% \mathrm{~S}$, but may have been present in suboptimal amounts at $3 \%$. That megalopa development was characterized by very high mortality in all three media at $3 \% \mathrm{~S}$ is somewhat surprising, since zoeae survived well at $3 \% \mathrm{~S}$ and adults are found at these salinities (Wurtz \& RoBack 1955, Ryan 1956, Pinschmid 1963).

These results indicate that commercially available synthetic sea salts are suitable for raising the larvae of at least one species of xanthid crab. Several factors must be weighed when choosing the proper medium. Its influence on the rate of development and survival is, of course, important. Cost should also be considered. If mass-rearing techniques will produce numbers in excess of experimental needs, a less expensive medium may be suitable even if it results in lower survival. Specific ionic composition, purity, and ease of preparation are also of importance.

If differences in developmental patterns exist due to the culture medium, a useful research tool is provided. In this study, two potential differences in development were noted that could be attributed to the culture medium. Synthetic sea water at low salinity delayed zoea development, and a marginally significant difference in mortality rate was noted among megalopa raised in the three media at $11 \% 00$. Such information can be used in at least two ways in further research. The influence of specific ion compostion and concentration on survival and development rate can be studied directly. In addition, specific media which produce different characteristic developmental rates can be used to study the influence of other factors, such as diet and temperature, on growth.

\section{SUMMARY}

1. Larvae of the xanthid crab Rhithropanopeus harrisii (Gould), were raised from hatching through the megalopa in natural sea water, and in two commercially available synthetic sea salts. Groups of larvae from the same hatch were raised at two salinities for each medium.

2. Hatching occurred successfully in all six media-salinity combinations tested.

3. Survival was high through the four zoea stages in all six test solutions. Statistical tests on cumulative zoea mortality showed no significant differences due either to salinity or to medium, and no interaction between them.

4. Survival dropped during the megalopa in all test solutions. Megalopa mortality was significantly higher in $3 \%$ than in $11 \%$. Although differences in mortality among the three media were apparent, statistical tests showed only marginal significance. No interaction between salinity and medium was evident. 
5. Rate of development through the zoea stages was affected by both salinity and medium although no interaction between these factors was evident. The following relationships among the six test solutions were demonstrated (from longest to shortest development): IO, $3 \%=7-\mathrm{S}, 3 \%$ \% 3 - $7-\mathrm{S}, 11 \%$ nsw, $3 \%=\mathrm{nsw}$ $11 \%=\mathrm{IO}, 11 \%$.

6. Differences among the three media in rate of megalopa development at $11 \% 0$ were only marginally significant (only one individual survived at $3 \%$ ).

7. It is concluded that either of the two synthetic media used is suitable for raising larvae of Rhithropanopeus harrisii.

8. The following criteria should be considered in choice of medium for raising larvae: influence on rate of development and survival, cost, specific ion composition, purity, and ease of preparation.

Acknowledgements. We wish to thank R. MILLER and D.PICKETT, who provided technical assistance during the course of this study. We also express our appreciation to Dr. T.S. Y. Koo for his helpful criticisms of the manuscript. Facilities for this study were provided at the Chesapeake Biological Laboratory, Solomons, Maryland, USA, by the University of Maryland. These studies were supported in part by a contract with the National Marine Fisheries Service and the State of Maryland Fisheries Administration (PL88-309, Sub-project No. 3-108-R-3, Contract No. N-043-340-72(G).

\section{LITERATURE CITED}

Chamberlain, N. A., 1962. Ecological studies of the larval development of Rhithropanopeus barrisii (Xanthidae, Brachyura). Tech. Rep. Chesapeake Bay Inst. 28, 1-47.

Connoliy, C. J., 1925. The larval stages and megalopa of Rhithropanopeus barrisii (Gould). Contr. Can. Biol. 2, 327-333.

Costlow, J. D., Jr. \& Boокноuт, C. G., 1960. A method for developing brachyura eggs in vitro. Limnol. Oceanogr. 5, 212-215.

- - \& Monroe, R., 1966. Studies on the larval development of the crab, Rhithropanopeus barrisii (Gound) I. The effect of salinity and temperature on larval development. Physiol. Zoöl 39, 81-100.

EWALD, J. J., 1965. The laboratory rearing of pink shrimp, Penaeus duorarum Burkenroad. Bull. mar. Sci. 15, 436-449.

Heinle, D. R., 1969. Culture of calanoid copepods in synthetic sea water. J. Fish. Res. Bd Can. 26, 150-153.

Mazur, J. E. \& Mrller, J. W., 1971. A description of the complete metamorphosis of the sea urchin Lytechinus variegatus cultured in synthetic sea water. Ohio J. Sci. 71, 30-35.

Millar, R. H. \& ScotT, J. M., 1968. An effect of water quality on the growth of cultured larvae of the oyster Ostrea edulis L. J. Cons. perm. int. Explor. Mer 32, 123-130.

Pnschmor, W. C., Jr., 1963. Distribution of crab larvae in relation to some environmental conditions in the Newport River Estuary, North Carolina. Manuscr. Duke Univ. $111 \mathrm{pp}$. (unpubl.).

Roberts, M. H., Jr., 1971. Larval development of Pagurus longicarpus SAY reared in the laboratory. II. Effects of reduced salinity on larval development. Biol. Bull. mar. biol. Lab., Woods Hole 140, 104-116.

Ryan, E. P., 1956. Observations on the life histories and the distribution of the Xanthidae (mud crabs) of Chesapeake Bay. Amer. Midl. Nat. 56, 138-162.

WiLson, D. P., 1951. A biological difference between natural sea waters. J. mar. biol. Ass. U. K. 30, 1-20. 
- 1958. Some problems in larval ecology related to the localized distribution of bottom animals. In: Perspectives in marine biology. Ed. by A. A. Buzzatr-Traverso. Univ. of Calif. Press, Berkeley, 87-103.

Wurtz, C. B. \& Roback, S. S, 1955. The invertebrate fauna of some Gulf Coast rivers. Proc. Acad. nat. Sci. Philad. 107, 169-206.

First author's address: Dr. S. D. Sulkin

Chesapeake Biological Laboratory

University of Maryland

Solomons, Maryland 20688

USA 